\title{
Reduction of Underwater-Radiated Noise from Ships: New Shipbuilding Challenge. The Vessels "Ramón Margalef" and "Ángeles Alvariño" as Technological References of How to Build Silent Vessels
}

Reducción del ruido radiado al agua por los buques: nuevo reto de la construcción naval civil. Los buques "Ramón Margalef" y "Ángeles Alvariño" referentes tecnológicos de cómo construir buques silenciosos

\begin{abstract}
Abatement of noise radiated by all kinds of vessels, and specially Underwater-Radiated Noise, because of its impact on marine life, has become the most outstanding novelty and the most difficult challenge the shipbuilding industry has ever faced. Hence, the industry seeks to offer new solutions to comply with the new guidelines and requirements that have been recently introduced and promoted by the EU, marine institutions, and the scientific community. This new topic, already studied and solved by the navies because of their strategic requirements, is now in the limelight and all the different aspects are being studied and discussed among the different players mentioned. In this new trend, the appearance of some class notations with "different limits", assertions such as that the "propeller" is the major noise source, and the absence of consensus among the biological community about what should be the limits (for not affecting marine fauna), it is difficult to define the technological steps that should be followed. Until a consistent agreement is reached, the shipbuilding industry and the naval engineers will be "fighting against a ghost". Within this "confusing scenario", this paper is a clear example of how the Spanish shipbuilding industry is moving ahead to reduce the impact of new ships. The dynamic and acoustic design, developed by the authors, of the fishing research vessels "Ramón Margalef" and "Ángeles Alvariño" for the Oceanographic Spanish Institute and the experimental results obtained, in full compliance with ICES N'209 Underwater-Radiated Noise requirements, makes them reference vessels for the construction of "Silent Vessels".
\end{abstract}

Key words: Underwater-Radiated Noise, Noise and Vibration on ships, Silent Ships

\section{Resumen}

La drástica reducción del ruido exterior generado por todo tipo de buques, y en particular el Ruido Radiado al Agua y su impacto en la fauna marina y los ecosistemas, se ha convertido en el mayor reto tecnológico actual de la construcción naval civil. Se busca con ello responder, de forma inmediata, a los nuevos y exigentes requerimientos y directivas de inmediata aparición que se han establecido dentro de las políticas de protección del medioambiente de la Unión Europea, instituciones marítimas y comunidad científica. Este nuevo aspecto, ya abordado por razones estratégicas por las flotas militares, se ha convertido, por sus implicaciones técnicas, económicas y medioambientales, en el epicentro de un intenso debate con participación de todos los actores mencionados. La aparición de nuevas notaciones de clase con "diferentes límites", la existencia de ciertos asertos o afirmaciones, poco soportadas experimentalmente (por la ausencia de datos) como que la "hélice es la fuente principal" del ruido radiado al agua, y la ausencia de consenso entre la comunidad biológica acerca de los "límites umbrales" de la fauna marina, dificultan, a juicio del autor, la correcta definición de la estrategia tecnológica a seguir. Mientras no se logre un "acuerdo" entre la comunidad científica y el sector marítimo sobre estos aspectos, podremos estar "combatiendo a un fantasma". Dentro de este "escenario confuso", el presente artículo es un ejemplo de cómo la construcción naval civil española está avanzando para reducir el impacto de los nuevos buques. El diseño dinámico/acústico de los buques oceanográficos "Ramón Margalef" y "Ángeles Alvarińo", del Instituto Español de Oceanografía, desarrollado por el autor, y los resultados experimentales obtenidos en cumplimiento con los estrictos Requerimientos ICES N²09 de Ruido Radiado al Agua, los convierte en "referentes tecnológicos" de cómo construir "buques silenciosos".

\section{Palabras claves:}

Date Received: September 28th, 2012 - Fecha de recepción: 28 de Septiembre de 2012

Date Accepted: February 7th, 2013 - Fecha de aceptación: 7 de Febrero de 2013 


\section{Introduction}

As previously mentioned and within the framework of the Green Policy of the EC and maritime institutions like IMO and ILO, all the targets defined focus on combating and reducing the current "environmental impact" of all types of vessels that make up the current European Fleet. To fulfil this main target, special EC R\&D projects have been promoted and launched to reduce emissions, as well as the Noise \& Vibration $(\mathrm{N} \& \mathrm{~V})$ environmental impact of the vessels.

A common conclusion reached from these projects [9] is that the N\&V-Full Signature (N\&V-FS) of the vessel is required to assess properly its environmental impact. This indicator is made up by the $\mathrm{N} \& \mathrm{~V}$ on board, Noise Radiated to Harbour (NRH), and the Underwater Radiated Noise (URN), being the URN and NRH the most outstanding novelty and, in the case of URN, the newest and greatest challenge to be faced.

In fact, very few data from "civilian vessels" regarding this aspect is available apart from some interesting results of URN measurements in the literature $[1,12,13,14]$. These publications are very interesting because several URN signatures of various commercial vessels (mainly cruise ships), are presented. These URN levels come with detailed descriptions of the measurement conditions and of the ships' characteristics, which allows data analysis. This lack of URN data is because no URN requirements are available in the vessel contract specification. The only exceptions are the fishing research vessels (FRV) because of their performance requirements (they must not disturb fish species during observations).

This unwanted trend, related to the absence of URN experimental data within the current fleet, has been totally confirmed by the analysis carried out by the SILENV project [3]. In the SILENV-N\&V database, generated from a total of 151 vessels, only five (3.1\% of the total sample) have included specific URN requirements in their contract specifications. To enrich this poor scenario, dedicated on-site measurement activities were carried out to obtain the URN signature of 10 additional vessels (of different types) and, therefore, more available experimental data was collected.

Other important points to consider are the current measurement procedures. As a first attempt to standardize these, ANSI-ASA launched its standard "Quantities and Procedures for Description and Measurements of Underwater Sound from Ships" [2]. This URN measurement standard is thought to perform measurements of the underwater sound pressure in the far field and deep waters (to avoid reflections). The procedure selected has no inherent limitation with regard to the vessel's size. Usually, the results are: the noise pressure levels in thirdoctave in decibels referenced to $1 \mu \mathrm{Pa}$ at $1 \mathrm{~m}$ from both hull sides. Band levels are associated with the mid-frequency of the third-octave band. For many purposes, it is convenient to use the power spectral density per unit bandwidth (spectrum level).

An important parameter is the transmission loss (TL) used to calculate the radiated noise at $1 \mathrm{~m}$ from the ship. The "real" transmission loss depends on many parameters (sound frequency, salinity, sea state, sea bottom, water depth, local sound velocity, etc.,) and obtaining a real and precise value would be quite difficult. That is why, in measurement standards, simplified methods are used to assess transmission loss (TL). Usually, the formula TL = 20 Log DCPA (DCPA: Distance of Closest Point of Approach) is applied for all the frequency bands (ANSI-ASA standard), which produce considerable uncertainties to the results of the measurement, especially for low frequency. Finally, ANSI-ASA does not define targeted limits.

Recently (in January 2010), DNV published a new standard to measure underwater noise emitted by ships [10]. This "SILENT" standard specifies targeted limits and associated measurement procedures for shallow waters. The method used to define these limits is not known. The different targeted limits specified in this new standard are different, depending on the type of vessel considered. According to this Class Notation, the Society, based on an operational speed profile for typical hydro-acoustic operations submitted to it, will decide the "speed at which the vessel shall 
be tested". It is important to keep in mind that based on the practical expertise of the authors, this parameter becomes essential for suitable dynamicacoustic design of silent vessels, and it should be defined and agreed at the beginning of the project. Likewise, in this Class Notation the TL is calculated according to the following formula: TL $=18$. $\log \mathrm{DCPA}-5 \mathrm{~dB}$.

Finally, since the 1990 s, the URN target limits defined by the ICES (International Council Exploitation of Seas) ${ }^{\circ}$ Regulation $N^{\circ} 209$ [11] became a widespread standard used within the
FRV family, especially in the modern ones. This standard specifies limits for $1 / 3$ octave spectrum levels, at a speed of 11 knots, as seen in Fig. 1.

Within the current regulation framework, several operational experiences have been compiled. The first ones are related with the URN on-site measurement data processing and data presentation. Fig. 2 reports the usual format for the presentation of the URN Spectra: Pressure (ref1 $1 \mu \mathrm{Pa}) @ 1 \mathrm{~m}-1 / 3$ Octave Band (1 $\mathrm{Hz})$ against Frequency $(\mathrm{Hz})$.

Fig. 1. ICES Regulation N²09. URN target limits at 11 knots

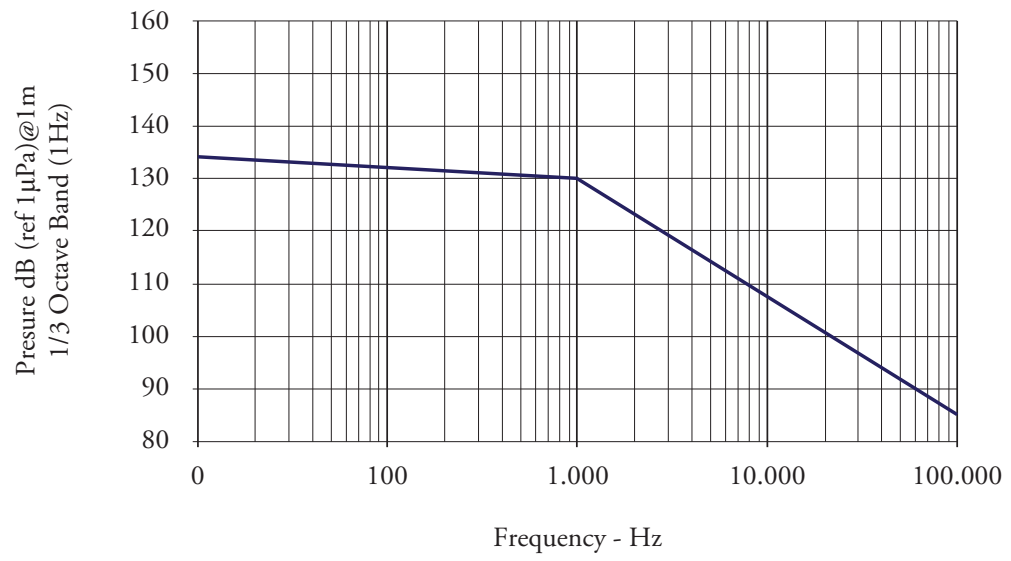

Fig. 2. Typical URN 1/3 Octave Band Spectra for Merchant Vessel at 28,5 knots

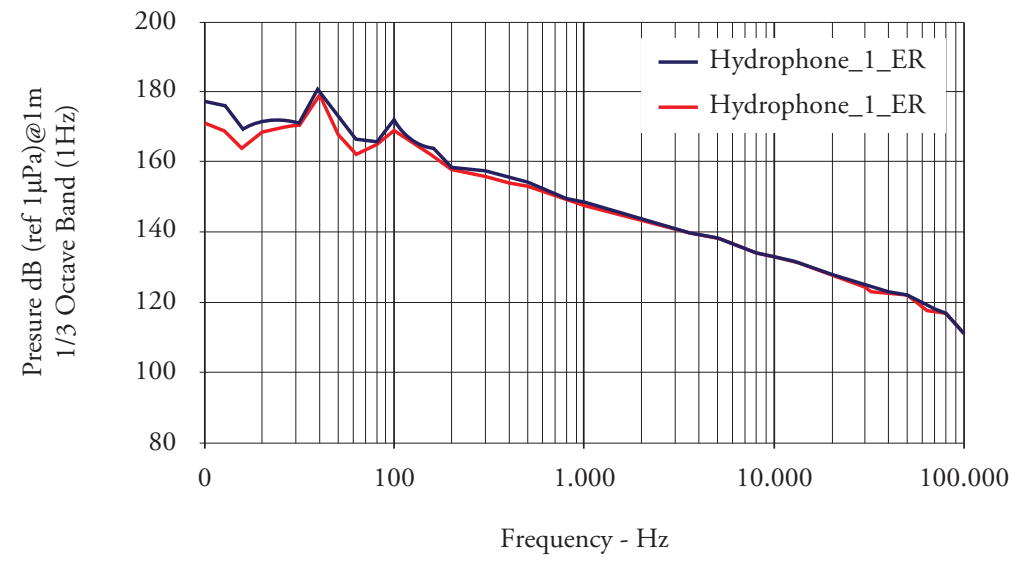

Finally, an intense debate to identify the main URN sources affecting the URN signatures of vessels has been opened. Traditionally, the propeller is considered the principal root cause of the URN signature of the vessels, with no experimental support. These kinds of assertions are made based on "old figures" and outdated information, where the propeller, of course, appeared as one of the main root causes of vibration on board. Based on the author's point 
of view, with 36 years of experience as $N \& V$ consultant in the marine sector, with these "assertions" the shipbuilding industry is confused and cannot manage to understand what needs to be done to move ahead on improving the current situation.

To shed light on this matter, within the framework of the SILENV project on-site measurement activities were conducted to obtain the URN signature with sufficient frequency accuracy to identify the main URN sources (machinery and propeller) in the spectrum (Fig. 3).

These experimental results have identified the machinery and the propeller (Fig. 4), in this order, as the main contributors to the URN signature in a significant sample of vessels of the current European Fleet. This approximation is sound enough with the experiences documented at Glacier Bay, mainly related to passenger vessels $[1,12,13,14]$. Currently, and based on these experimental data, the message to the shipbuilding industry is clear: abatement of the URN signature of "new vessels" will require preventive control of the sources and actions focused on reducing vibration energy transmission from main mechanical sources, like main machinery, to the hull. The intensity of the excitation induced by the propeller must be controlled, as well as its cavitation.

Fig. 3. Narrow band analysis for accurate identification of URN contributors

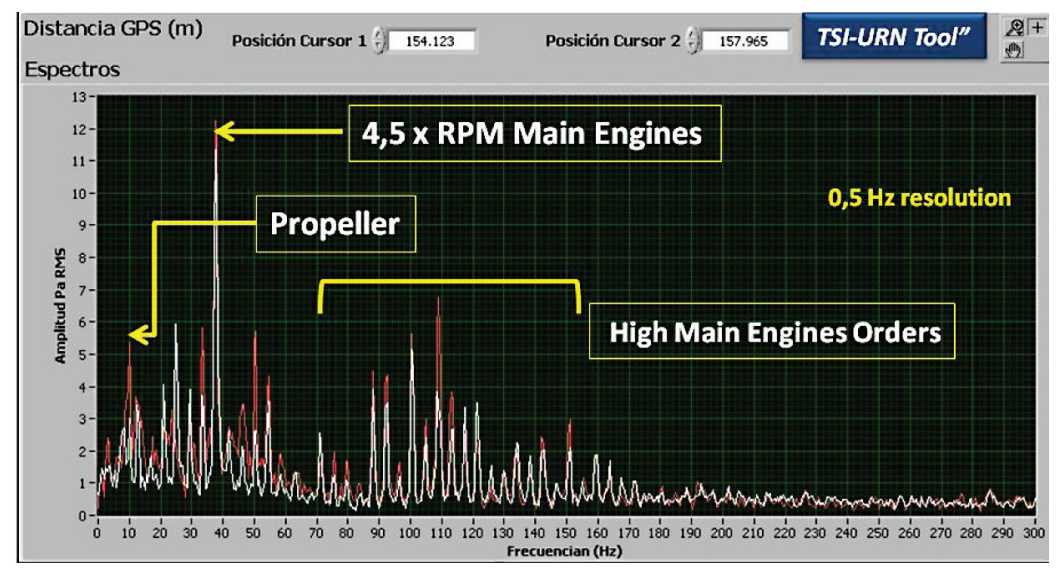

Fig. 4. Statistical Assessment. URN Root cause/s identification

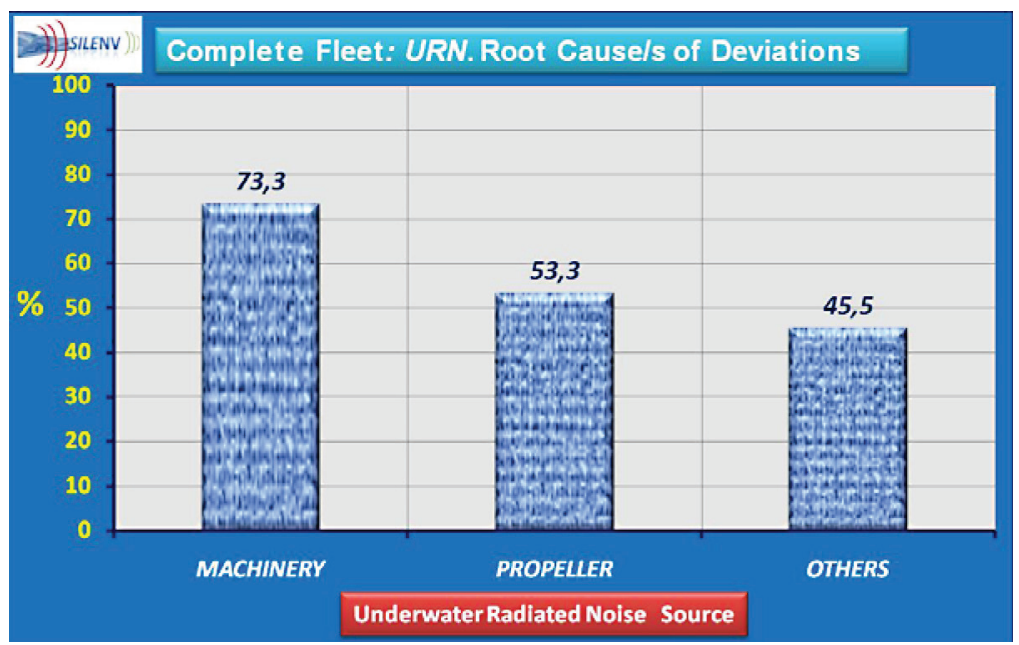


Therefore, as a summary we can conclude that, first of all, it is unquestionable that the current debate amongst the scientific and technical marine communities as far as the impact of the underwater footprint of commercial vessels on marine life is concerned, is in the limelight. On the other extreme, we can find the current fleet for which, with very few exceptions (FRVs), there are no specific URN requirements included in their contract specifications. Consequently, availability of URN data is limited and, hence, impossible to accurately assess the real impact of each family of vessels on the oceans and on marine life. To move ahead in filling this URN data void, special mention should be made of the experimental database generated within the framework of the BESST and SILENV projects.

Other reasons for the current state are the novelty that this topic means for the civilian shipbuilding industry and, from the author's point of view, "the general confusion" in relation with the harmonization of the measurement procedures and about the limits. The ICES Regulation $\mathrm{N}^{\circ}$ 209 limits appear, for some scientists, "still quite permissive" but excessive for the shipbuilders. So, the conflict remains unresolved. As will be detailed in the conclusions, harmonization, improved measurement procedures, and a "preliminary agreement" as far as the targeted limits are concerned between the scientific community and the marine sector is vital to define the technological strategy that should be followed to improve the current situation.

Based on the author's expertise in building "silent ships", the FRV family, especially the most modern ones, becomes a point of reference and a clear example of the technological strategy that must be applied to minimise the impact of the vessels in the Oceans. They are a "Technological reference" because it will be possible to look at what types of dedicated solutions have been applied on them to reduce their URN signature. Of course, it must be kept in mind that other factors like cost/benefit ratios, fuel efficiency, and technical viability should be considered and properly weighted. Besides, they will also be a "strategic reference" because it will be possible to discover why the FRV family, contrary to the other ones, is fighting and moving ahead in the abatement of their underwater footprints. Certainly, it will enable increasing the level of sensitization of the rest of the fleet with regard to this new topic.

\section{Case Studies: Frv "Ramón Margalef" \& Frv "Ángeles Alvariño"}

\section{Introduction}

At the end of August 2011, the FRV "Ramón Margalef" and, in the summer of 2012, the FRV "Ángeles Alvariño", which are almost twin ships, were delivered to the Spanish Oceanographic Institute (IEO, for the term in Spanish). As a result of the sea trials, the following main aspects could be highlighted: for the "Ramón Margalef" the maximum vibration level on board was 0.7 $\mathrm{mm} / \mathrm{s}$-rms; noise on board at cabins was between 37 and $57 d B(A)$ and $87 d B(A)$ at the engine room; noise levels radiated to harbour $(\mathrm{NRH})$ in compliance with EC Directive 2006/87 (lower than $65 \mathrm{~dB}(\mathrm{~A})$ at $25 \mathrm{~m}$ from both hull sides); and noise radiated to the water (URN) in compliance with ICES Regulation N²09. For FRV "Ángeles Alvariño", the maximum vibration level on board was $0.7 \mathrm{~mm} / \mathrm{s}$-rms; noise on board at cabins was between 50 and $55 \mathrm{~dB}(A)$; and noise radiated to the water (URN) practically in compliance with ICES Regulation $N^{\circ}$ 209. These experimental results, respecting the strictest $\mathrm{N} \& \mathrm{~V}$ comfort and environmental requirements, placed the "Ramón Margalef" and "Ángeles Alvariño" among the "most silent" vessels of all the European Fleet and perhaps of the civilian fleet in the world. Thus, these vessels have become a clear milestone and indicator that the European and Spanish shipbuilding industry is capable of meeting the current needs focused on abating the $N \& V$ environmental impact of vessels.

These results are not a question of luck; they are based on solid pillars: the first one is the high level of sensitization shown by the owner (IEO), who defined a technical specification that included specific requirements to guarantee: comfort and good working conditions of the crew and scientists, 
reduction of the vessel's environmental impact, and, of course, the high efficiency of the scientific echo-sounders on board. Indeed, SIMRAD/ KONSBERG, in another FRV in which the same methodology described below has been applied by the authors, confirmed that the "low background noise of the vessel" has enhanced the efficiency of the electronic equipment by more than $40 \%$.

On the other hand, the excellent experimental results obtained enable validating and consolidating the "Noise \& Vibration Integrated Management" methodology the author has been applying for over 36 years.

The aim of this paper was to present a brief description of the "N\&VIntegrated Management" methodology applied in the "Ramón Margalef" and "Ángeles Alvariño" FRVs. It is widely detailed in other authors' publications [3, to 8]. A summary of the experimental results obtained during the sea trials are also presented.

Description and main particulars of the vessels

Because of its size and capacity, the FRV "Ramón Margalef" is classified as a regional fishing research vessel. It has autonomy for 12 days and can provide accommodation for 11 researchers and technician staff, in addition to a crew of 12 members. The "Ramón Margalef" has diesel-electric propulsion made up of three gen-sets driven by GUASCOR F480TA-SG diesel engines with an output of $868 \mathrm{~kW}$ at $1,500 \mathrm{rpm}$, elastically mounted according to the criteria defined by the consultant (the author). This plant produces all the power required to drive the two INGETEAM-INDAR KN-8005-b-"c" DC electric motors, as well as all the electric power for the ship's on board services and machinery. The vessel has two shafts each driving a single fixed-pitch propeller. The main particulars and an overview of the vessel are reported in Fig. 5. The "Ángeles Alvariño" has the same characteristics as the "Ramón Margalef" except that it has only one shaft driving a single fixed-pitch propeller.
Fig. 5. Vessel's overview and main particulars

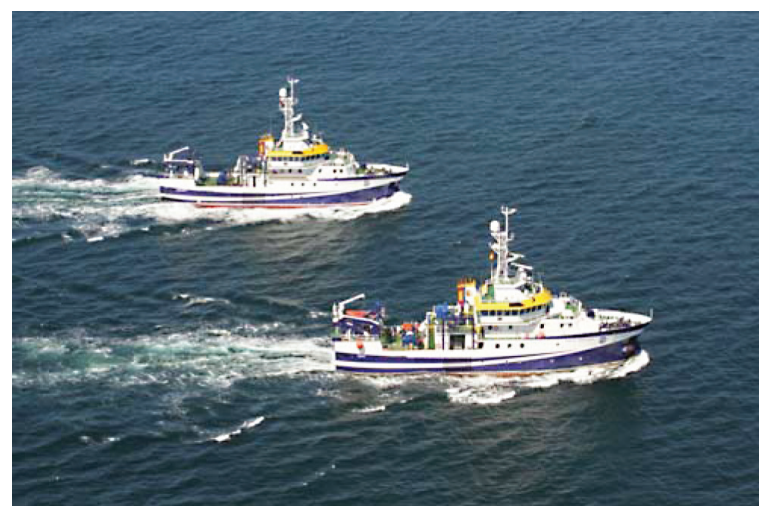

\begin{tabular}{|c|c|}
\hline Length overall & $46.70 \mathrm{~m}$ \\
\hline Maximum breadth & $10.5 \mathrm{~m}$ \\
\hline Design draft & $4.00 \mathrm{~m}$ \\
\hline Depth to deck $\mathrm{N}^{\circ} 3$ & $7.10 \mathrm{~m}$ \\
\hline Gross tonnage & $988 \mathrm{t}$ \\
\hline Dead weight & $230 \mathrm{~T}$ \\
\hline Main propulsion & $2 \times 900 \mathrm{~kW}$ \\
\hline Maximum speed & 13 knots \\
\hline Classification & BUREAU VERITAS \\
\hline
\end{tabular}

The "N\&V Integrated Management" Methodology

Vessels are elastic systems under periodic forces from different sources. Consequently, they are vibration sensitive. The vibration levels obtained in the system (the vessel) depends, mainly, on three parameters: 1) intensity or magnitude of the excitation forces; 2) structure stiffness; 3) dynamic amplification at different frequencies due to resonance phenomena: local and global. Consequently, the possible actions that could be implemented if we want to keep vibration levels under certain limits are the following: A) minimise the system's excitation forces; B) avoid flexible structures from a dynamic point of view; C) avoid resonance phenomena (coincidence of structural frequencies and excitation frequencies). Similarly, and from an acoustic point of view, the vessel has built-in sonorous sources: main and auxiliary engines, propellers, hydraulic systems, HVAC, etc., airborne and structureborne noise generators. The noise is transmitted 
or spread throughout the structure of the vessel (path) and reaches all the different locals and spaces (receptors) and it is also radiated to the water. Likewise, the possible actions that could be implemented to maintain noise levels under the predefined limits are the following: 1) minimise the sound power and vibration power at the noise sources; 2) reduce or diminish their transmission to the paths; 3 ) isolate the receivers.

From an elastic-acoustic point of view, the hull becomes a wave radiator to the water due to the acceleration induced on it by the action of the main mechanical excitation sources and to the propeller. In this case, preventive actions and sources control shall be applied focused on reducing the vibrational energy transmitted to the hull by the main machinery and by the propeller. Thereby, dedicated factory acceptance tests (FAT) (for the main machinery) should be conducted, pressure pulses induced by the propeller and cavitation tests should be carried out to avoid this phenomenon. For the practical application of the previous "basic principles", inside the "Noise and Vibration Integrated Management" (N\&VCM) and as a control mechanism, "dynamic and acoustic specific requirements" have been incorporated in the purchase specifications of the different supplies, as well as FAT procedures to control and verify their compliance before installing the most critical supplies on board. This "first activity level" has focused on the fact that the shipyard can develop a "control" of the main N\&V and URN sources that are usually under the scope of suppliers. The intention with this "control mechanism" is to achieve and guarantee the so-called "contractual sensitivity" of the suppliers towards the dynamic and acoustic objectives of the project. If this easy task is not performed, the shipyard finds that, on many occasions, the solutions or countermeasures that should be implemented are more expensive. The vast expertise of the suppliers involved in similar projects has permitted, for the case of the "Ramón Margalef", easy and efficient control.

The Shipyard assumed, from the beginning of the project, the fact that the "Dynamic and Acoustic Vessel Design" is mandatory. Thus, once the N\&V main sources were under its control, a "second module or block of activities" that considered all the aspects that are competence of the shipyard like supplying a vessel structure with appropriate dynamicacoustic design - with no resonances and with enough acoustic isolation to guarantee compliance with $N \& V$ contract requirements. Focused on achieving these $\mathrm{N} \& \mathrm{~V}$ targets, a whole dedicated package of simulation tools and dynamic tests, such as $\mathrm{N} \& \mathrm{~V}$ prediction calculations (Fig. 6) and radiated noise: outdoor and underwater, prediction calculations, were brought into play to achieve the optimal design.

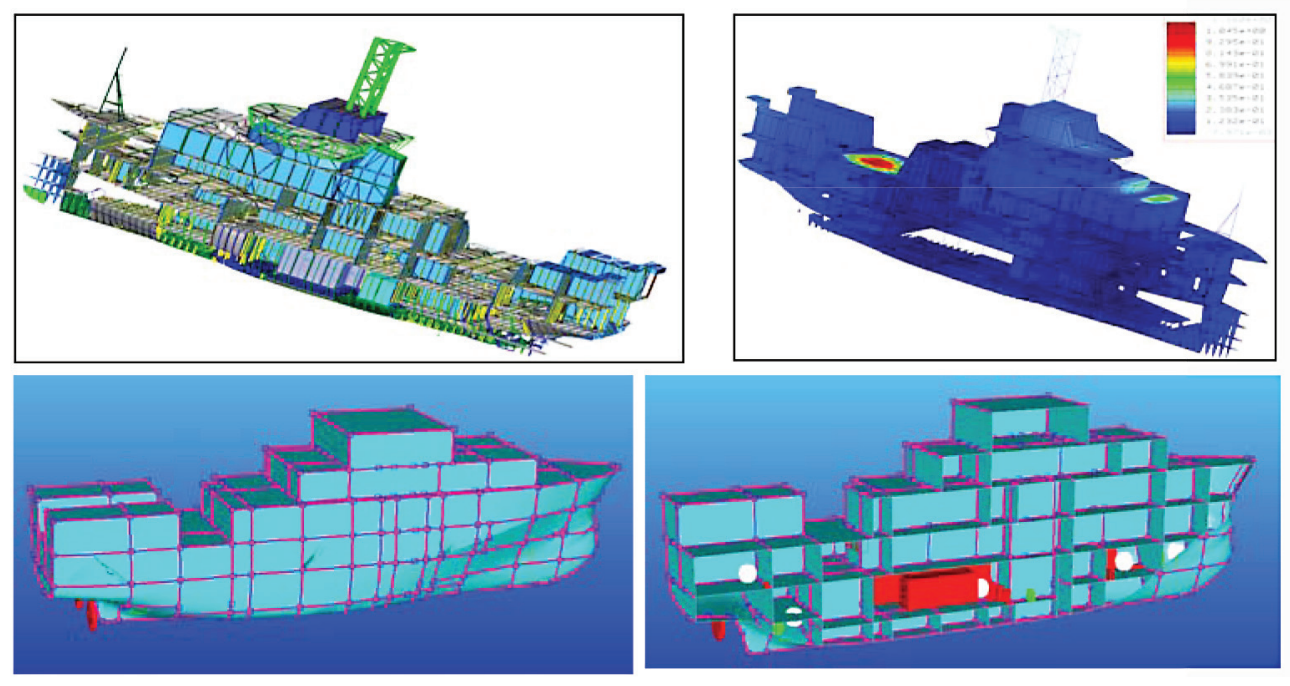


To verify fulfilment of the "design criteria" defined by the consultant, related to the intensity of the excitations induced by the main machinery and by the propeller, as well as the theoretical results provided by the simulation tools applied, a whole package of model tests and on-site dynamic tests: FAT and Inertance Tests (Fig. 7) have been applied at different stages of the project.

Fig. 7. FAT, Inertance and Model tests developed for the "Ramón Margalef" design
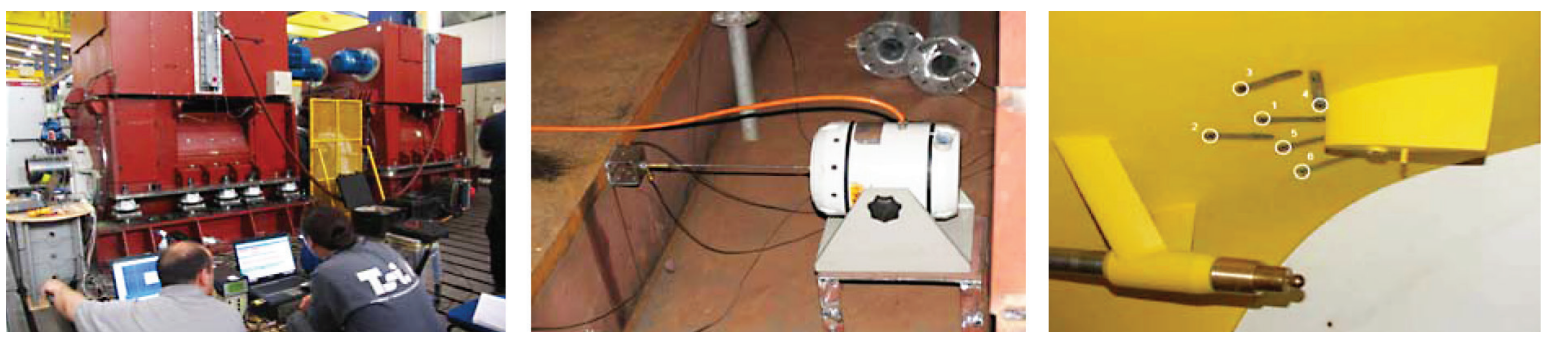

After this entire analytical-experimental process, the vessel is ready to pass the most important test: the sea trials.

\section{The sea trials: Results}

All the sea trial measurements were performed at the Vigo Bay (Spain) according to protocols previously approved by the owner, the shipyard, and BUREAU VERITAS. Some of the results are summarised in the figures ahead.

\section{Noise on board}

For the Accommodation / Laboratories-Public, and Engine Room/Work spaces, the noise results obtained have been reported through bar diagrams (Figs. 8 and 9).

The numerical results reveal that:

"Ramón de Margalef": For accommodation and laboratory/public spaces, the noise on board average values are -9.6 and $-10.1 d B(A)$, respectively, lower than the corresponding $\mathrm{BV}$ COMF VIB 1 limits $(55,60$, and $65 \mathrm{~dB}(\mathrm{~A})$, respectively). A special mention must be made of noise levels achieved in the engine room and in the machinery spaces with an average value of $-32.6 d B(A)$, lower than the BV's limit (110

Fig. 8. "Ramon Margalef" noise on board: accommodation and engine room spaces

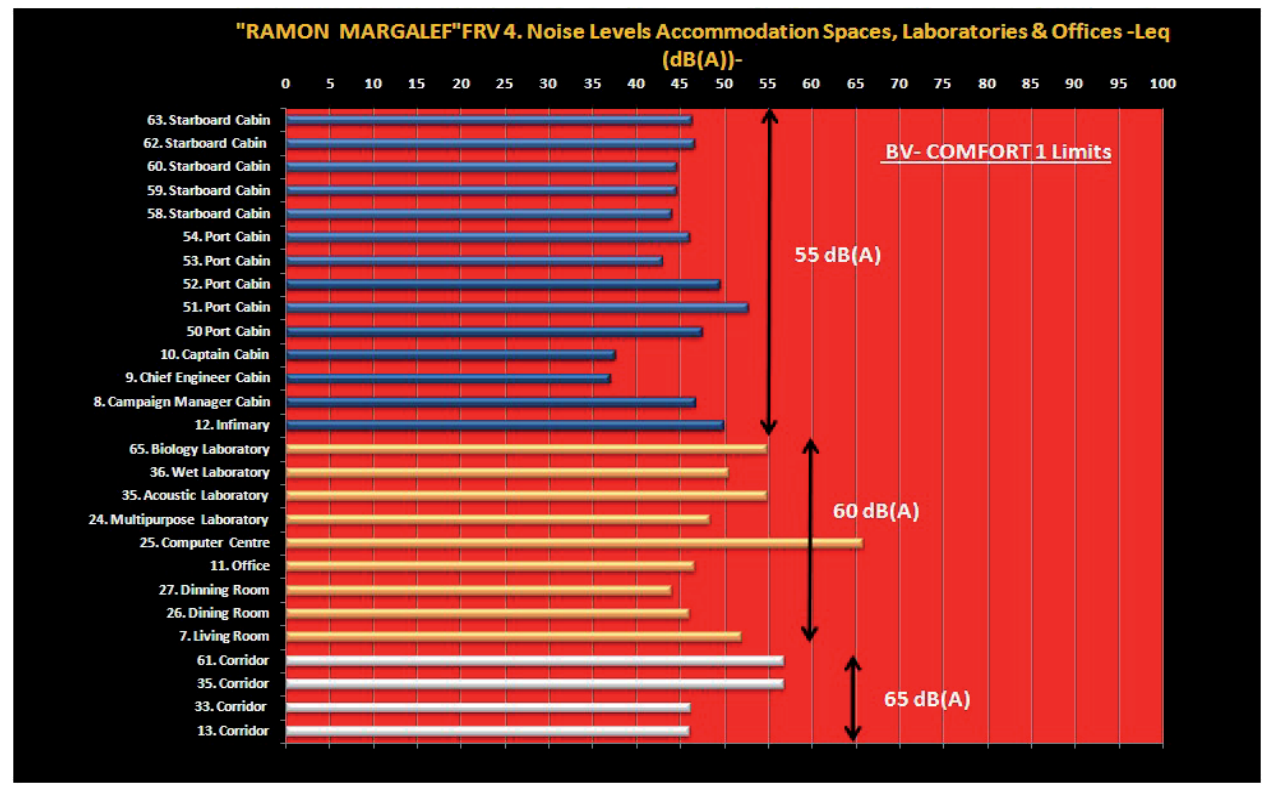




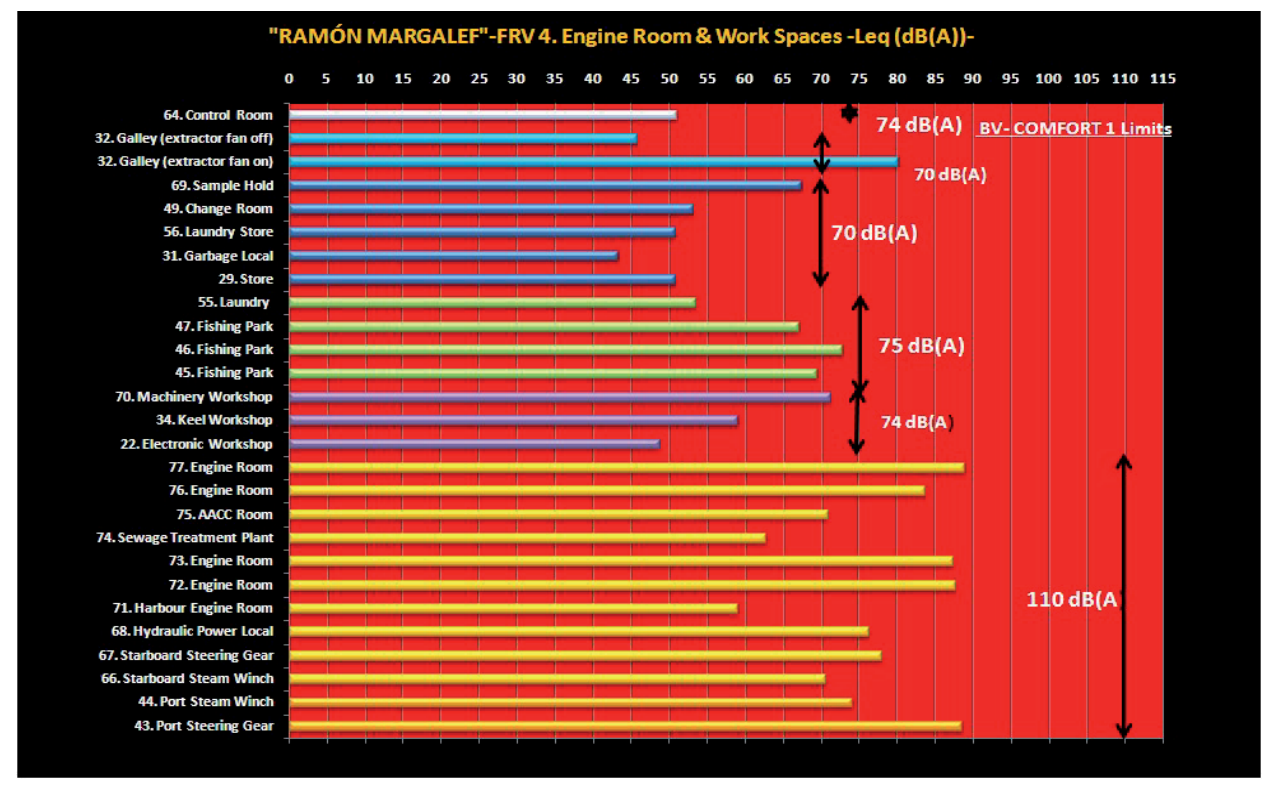

$\mathrm{dB}(\mathrm{A})$ ) and than the new IMO amendment limits, in progress.

"Angeles Alvariño": For accommodation and laboratory/public spaces, average values of noise on board are -2.7 and $-6.2 d B(A)$, respectively, lower than the corresponding BV-COMF VIB 1 limits.

\section{Vibration on board}

For the accommodation/laboratories-public, and engine room/work spaces, the vibration results obtained are reported in the bar diagrams in Figs. 10 and 11.

"Ramón de Margalef": For a total of 36 locations at the accommodation and laboratory/public spaces, the average vibration on board achieves a significant value of $-2.7 \mathrm{~mm} / \mathrm{s}-\mathrm{rms}$, lower than the corresponding BV-COMF VIB 1 limit $(3 \mathrm{~mm} / \mathrm{s}-$ rms). A Special mention must be made again for

Fig. 9. "Ángeles Alvariño" noise on board: accommodation and engine room spaces

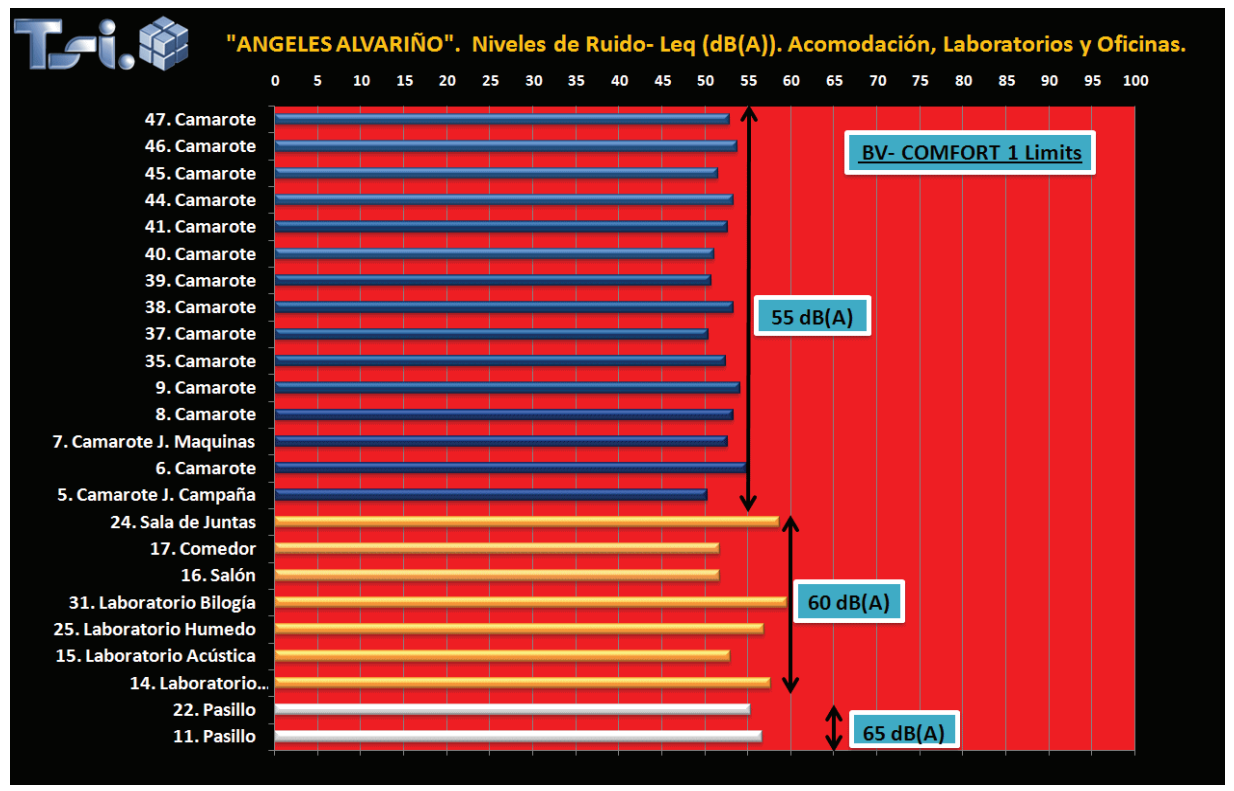




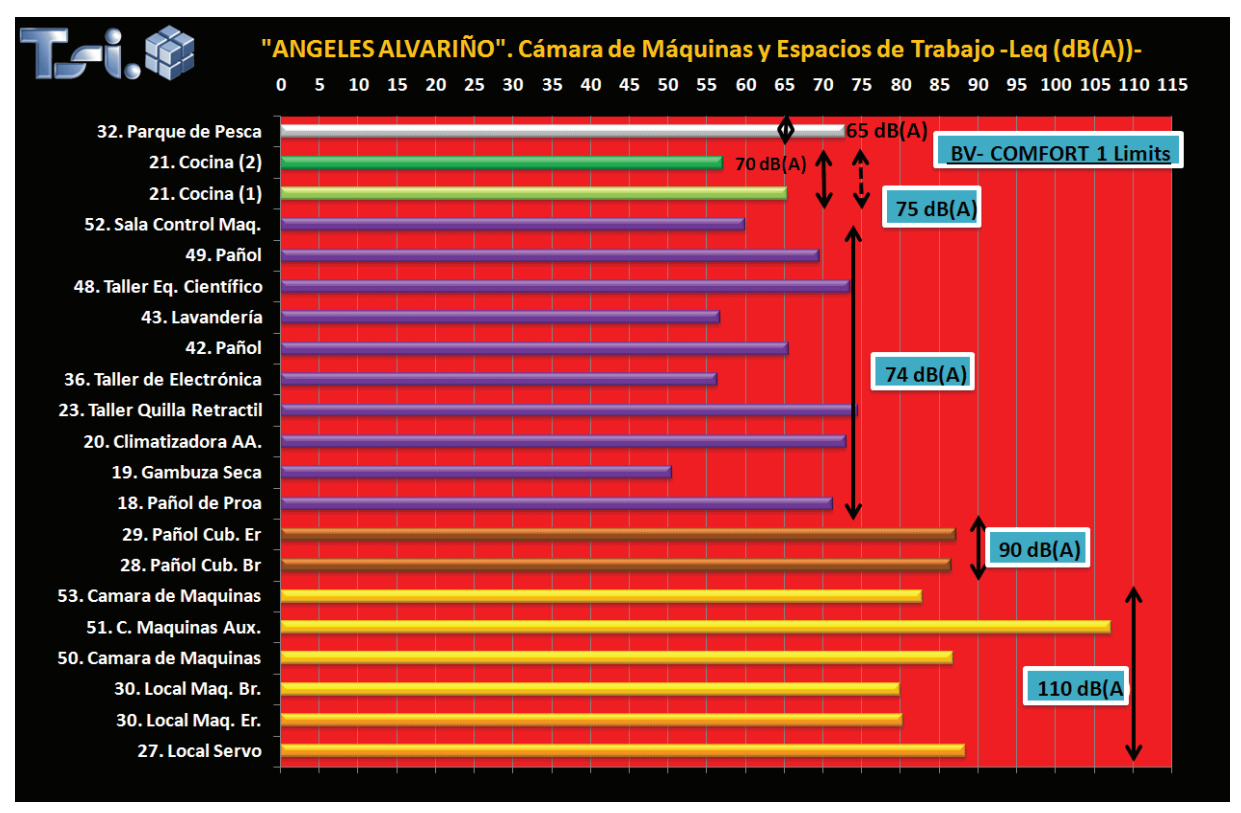

the vibration levels at 23 locations in the engine room and in the machinery spaces with an average deviation of $-3.7 \mathrm{~mm} / \mathrm{s}-\mathrm{rm}$, when compared with the corresponding BV-COMF VIB $1(4 \mathrm{~mm} / \mathrm{s}-$ rms).

"Ángeles Alvariño": As with the previous vessel, for a total of 36 locations at the accommodation and laboratory/public spaces the average vibration on board achieves a significant value of $-2.7 \mathrm{~mm} / \mathrm{s}-\mathrm{rms}$, lower than the corresponding BV-COMF VIB 1 limit ( $3 \mathrm{~mm} / \mathrm{s}-\mathrm{rms})$, and in the engine room and machinery spaces with an average deviation of $-3,6$ $\mathrm{mm} / \mathrm{s}-\mathrm{rms}$, when compared with the corresponding BV-COMF VIB 1 ( $4 \mathrm{~mm} / \mathrm{s}$-rms). All these values are a clear indicator of the low vibrational energy distribution achieved along the vessel's structure due to the preventive actions adopted.

Fig. 10. "Ramón Margalef" vibration on board: accommodation and engine room spaces

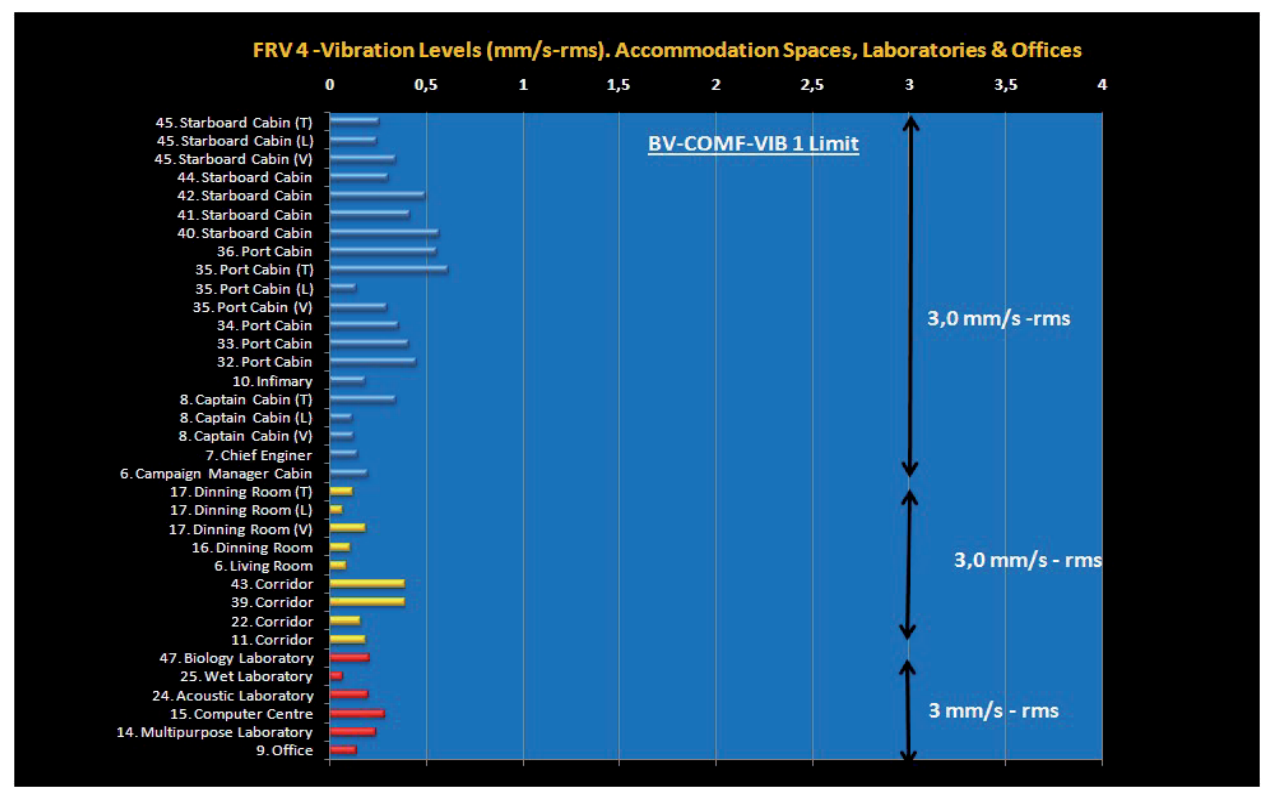




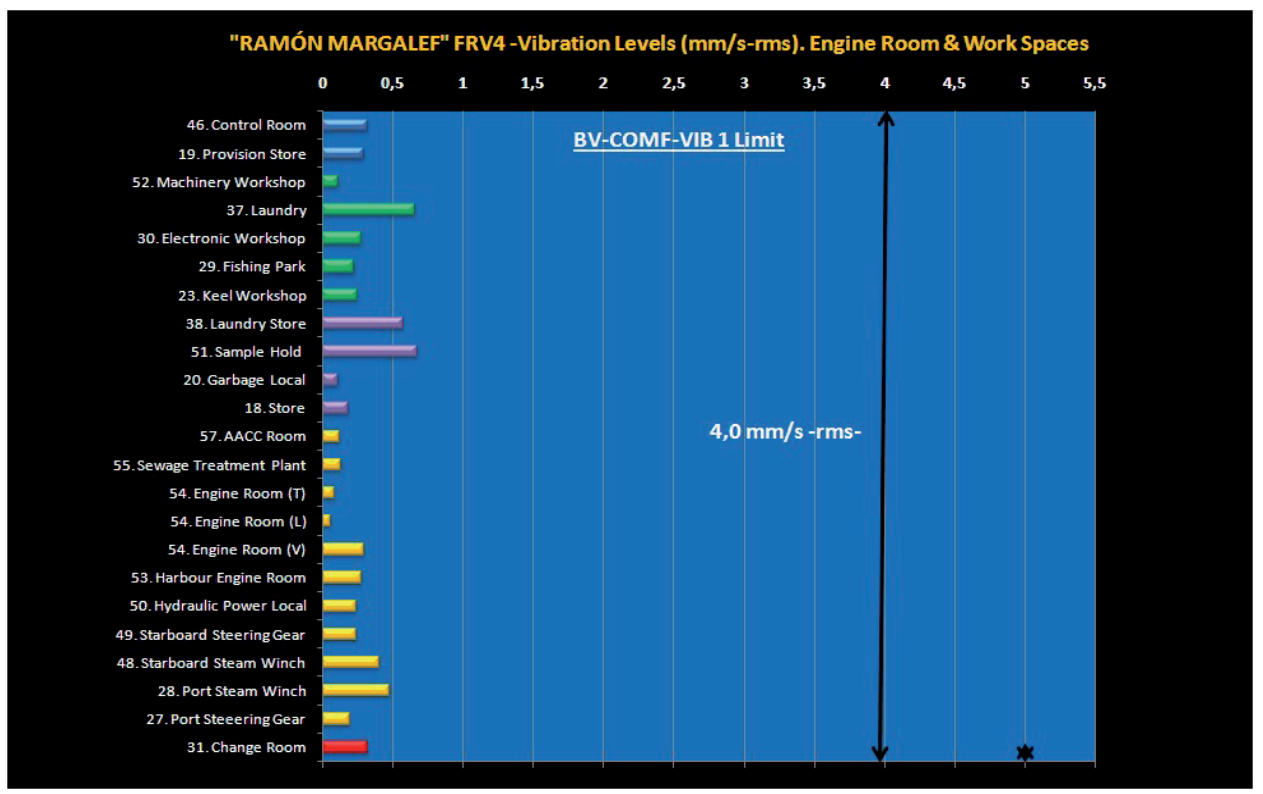

\section{Noise Radiated to Harbour (NRH)}

"Ramón Margalef": The corresponding results related to this topic are reported in Fig. 12 and were carried out within the framework of the onsite measurement activities of the SILENV project (which is why "Ángeles Alvariño" does not have the NRH signature). As noted, the outdoor noise levels at $20 \mathrm{~m}$ from the starboard hull-side along the whole length of the "Ramón Margalef" are below $65 \mathrm{~dB}(\mathrm{~A})$, according to the preliminary SILENV limits adopted and the limits established by EC Directive 2006/87 and by ISO 2922/200 Acoustic [15].

\section{Underwater-Radiated Noise (URN)}

A sequence of the URN measurement tests and the results obtained in terms of URN pressure (ref $1 \mu \mathrm{Pa}) @ 1 \mathrm{~m} \mathrm{1/3}$ Octave Band Spectra $(1 \mathrm{~Hz})$ at an

Fig. 11. "Ángeles Alvariño" vibration on board: accommodation and engine room spaces

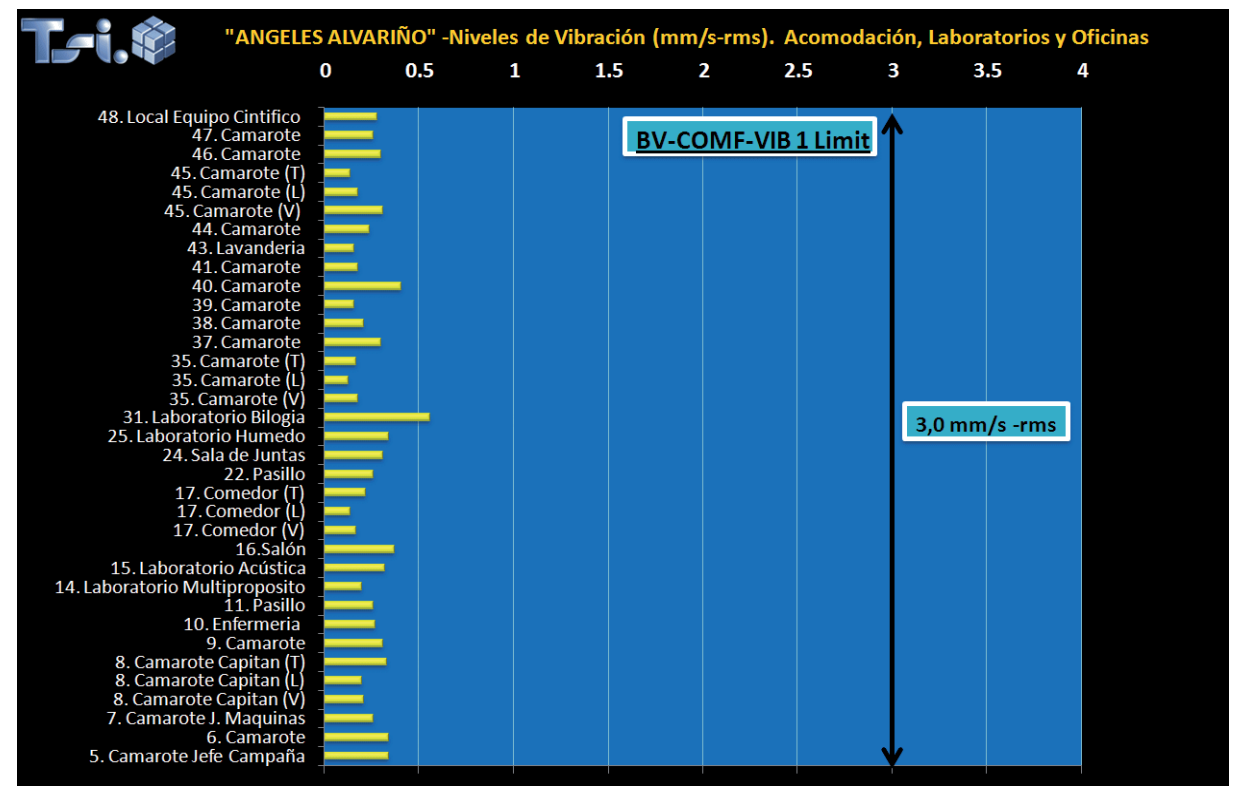




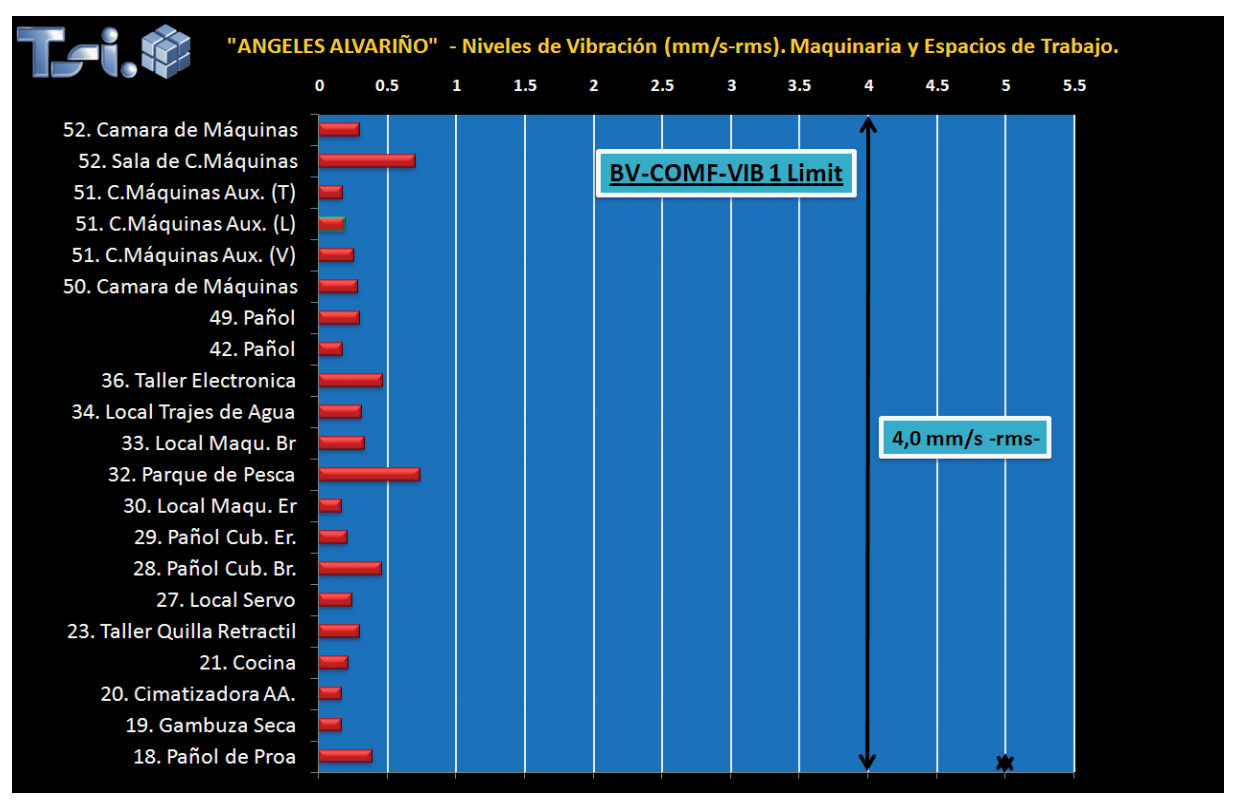

Fig. 12. "Ramón Margalef" starboard hull side outdoor noise levels
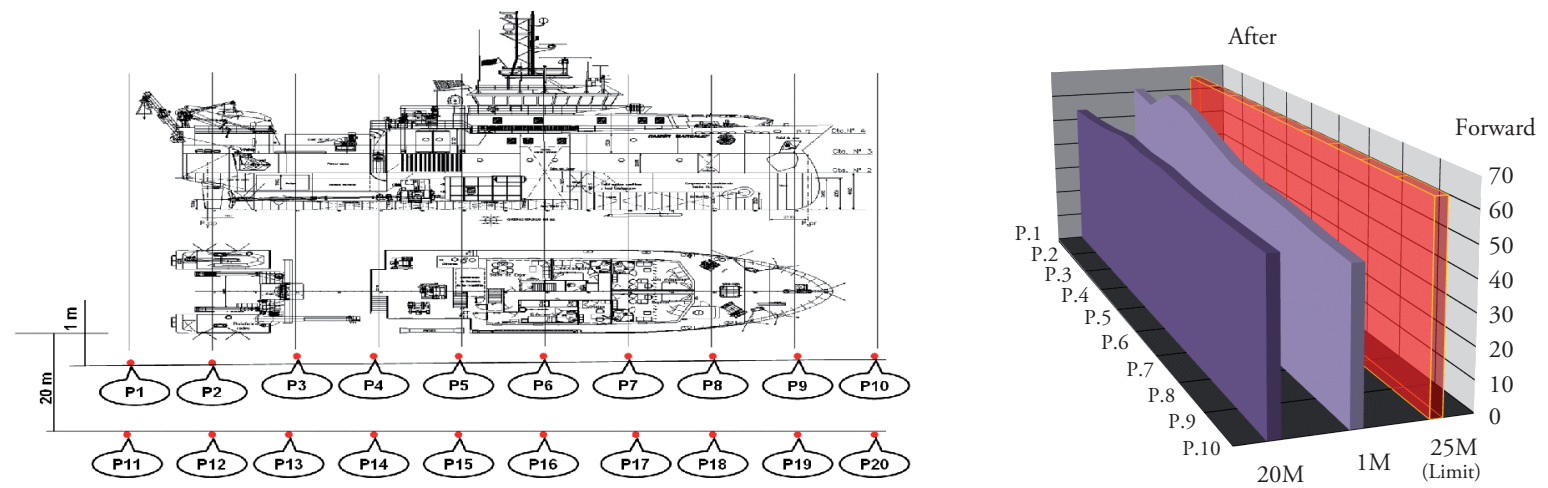

operational speed of 11 knots, for both hull sides, are reported in Figs. 13 and 15.

"Ramón Margalef": examination of Fig. 13 enables us to state that the FRV "Ramón Margalef" complies with the ICES Regulation No 209 [11]. The narrow band analysis has permitted proving that the small deviations observed at low and high frequencies are not related to URN sources but to the disturbance that the measuring device suffered because of the sea state and because of some interference that came from a meteorological sound-buoy operating in the area.

Finally, as a complementary "external indicator" of the low underwater footprint of the FRV "Ramón
Margalef", Fig. 14 shows the "high resolution" of the data obtained by IEO scientists (courtesy of SIMRAD/ KONSBERG) with the on-board echosounders, during the geological research carried out by the vessel in its first investigation about the sudden appearance of a new volcano in the coast of "El Hierro Island" (Canary Islands - Spain).

"Angeles Alvariño": examination of Fig. 15 allows us to state that this FRV almost complies with the ICES Regulation No 209 [9]. The narrow band analysis and the comparison of these results with the ones corresponding to the "Ramón Margalef" has permitted proving and confirming that the small deviations observed are due to the existence of a single shaft driving a fixed-pitch propeller, 
Fig. 13. "Ramón Margalef" URN measurements \& URN 1/3 Octave Band Spectra @ 11 knots
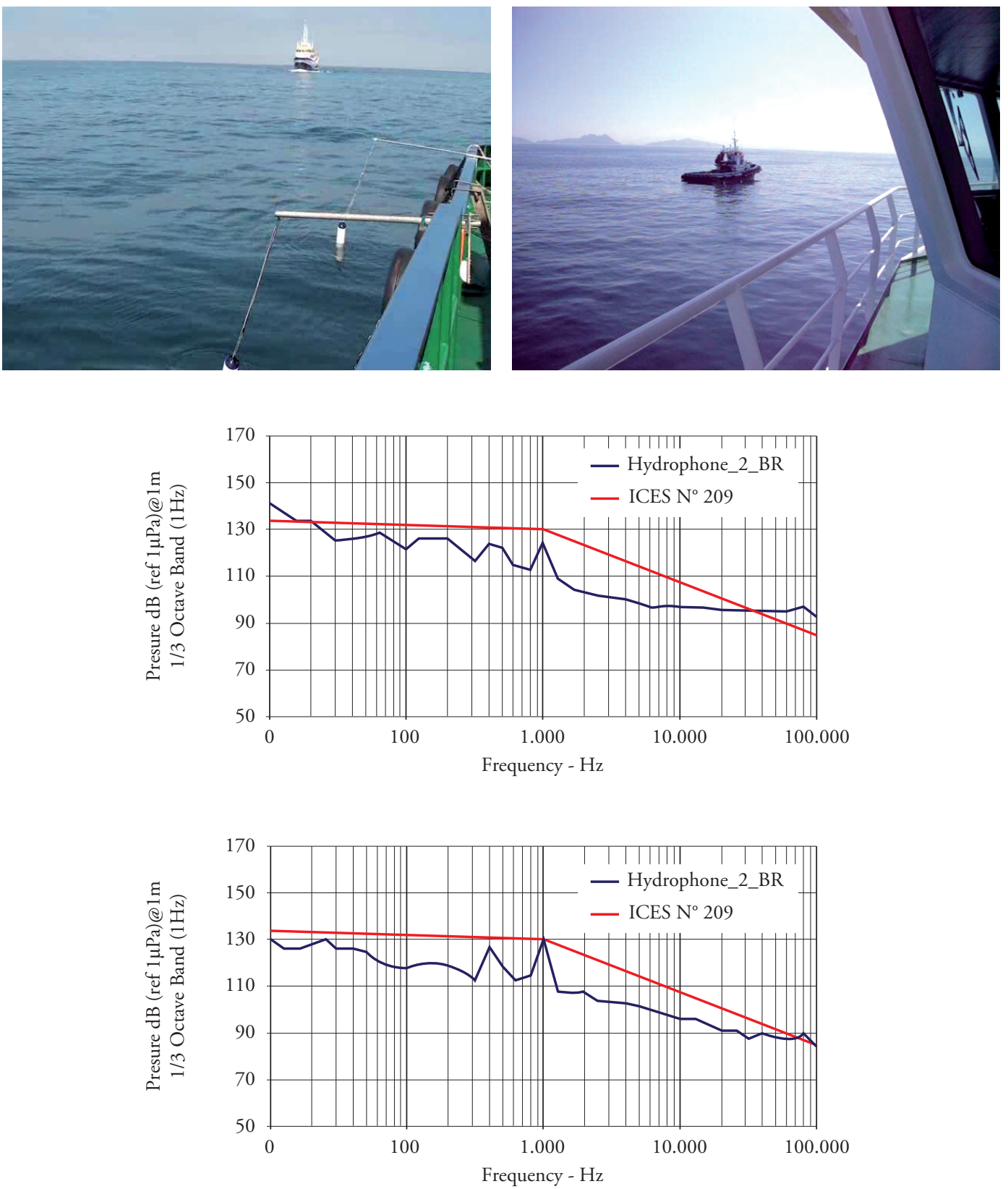

Fig. 14. "Ramón Margalef" geological data on appearance of new volcano (courtesy of SIMRAD)
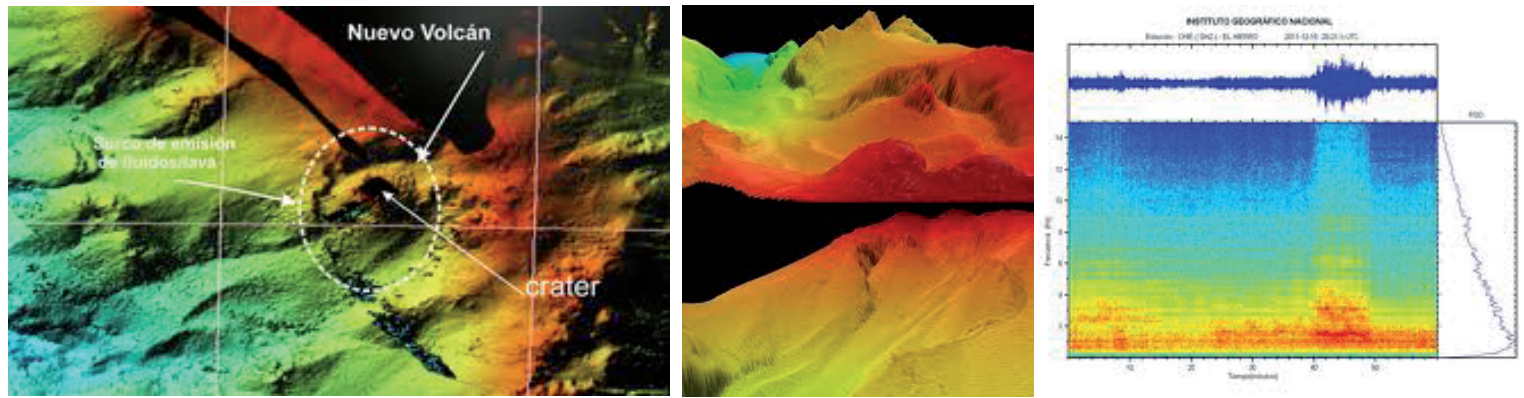
Fig. 15. "Ángeles Alvariño” URN measurements \& URN 1/3 Octave Band Spectra @ 11 knots

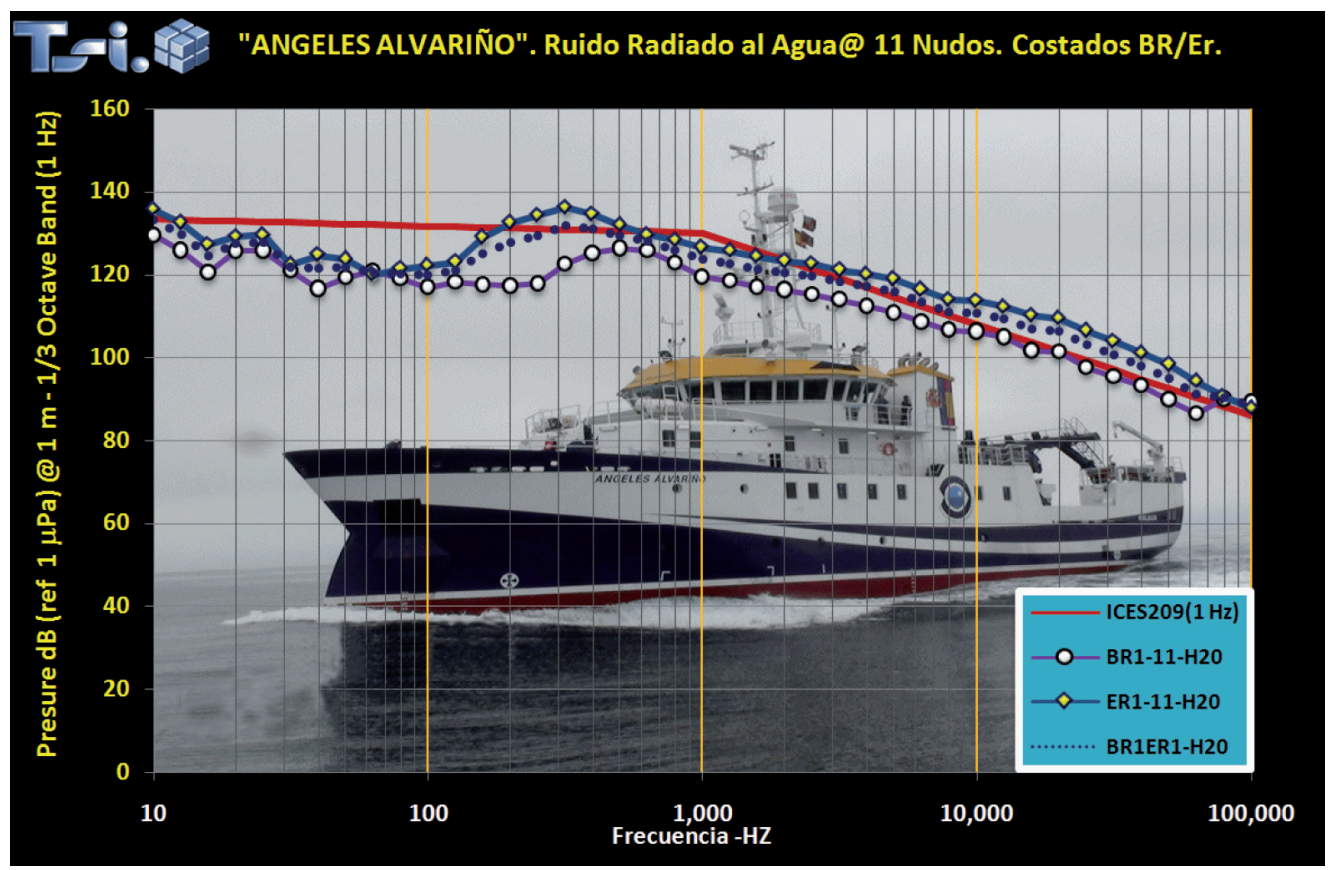

which produces flow problems at the stern of the vessel because the inflow to the propeller is not as good as in the FRV "Ramón Margalef".

\section{Conclusions: "Lessons Learnt"}

Some of the most interesting conclusions and lessons learnt, according to our judgement, are detailed as follows:

- The experimental results support the FRV "Ramon de Margalef" as a civilian technological reference within the field of "silent vessels", showing that the European and the Spanish shipbuilding industry is ready to meet the current and future environmental requirements within the framework of the new EC Green Policy.

- The practical cases of the FRV "Ramón Margalef" and "Angeles Alvariño" have shown the validity of the "N\&V Integrated Management" methodology to be applied as a practical guide in designing and building "silent vessels". This methodology can also be applied for commercial vessels considering and properly weighting the cost/benefit ratio, fuel efficiency, and technical viability.
- Once these two essential pillars: shipbuilding capabilities and availability of successful "practical guides" have been consolidated, the "battle against high noise levels in the Oceans" requires, from the author's point of view, establishing clear, well-founded, and coordinated policies based on the following points:

- Technological: Harmonization of measurement procedures and improvements in measuring devices and in the acquisition and post-processing process, are essential. Precise identification of the "enemies" (URN sources), to properly confront them, will not be submitted to "unfounded assertions", but will be based on consistent experimental results.

- Preliminary Limits Definition: The target is "to reduce the underwater noise to protect marine fauna". Two key questions arise and need to be answered: How much must we reduce the noise? (Unfeasible for the current fleet); and How much will it cost for a new vessel? A first consensus between the scientific community and the shipbuilding industry is essential if some preliminary URN limits are to be defined. 
Perhaps these preliminary limits are not as strict as many biologists would like, but they will obligate the shipbuilding industry to move ahead and assess the impact that achieving these limits has on the costs, thus, their technical-economic viability.

- Regulatory Framework: The complete lack of URN requirements in contract specifications has been confirmed as the main cause of URN data unavailability. The premise "no one does anything if they are not forced to" is well stated. This status needs to be changed and to do so, the following actions must be carried out: Firstly, there should be thorough dissemination of the EC policy within the marine sector (currently immersed in a "difficult crisis") focused on not "forcing" but "convincing" about the advantages of fighting against the URN impact. Secondly, the lack of URN data for most of the current fleet hindered suitable "URN management" and identification of vessels that should not enter protected areas. The URN signatures from a representative sample of vessels are, therefore, needed, independently of the compliance with whichever the URN limits are. The same criteria should be applied for the new constructions.

- Finally, retrofitting old vessels to reduce the current underwater noise levels is technically and economically unfeasible. Fleet renewal must be based on full compliance with "environmental requirements: emissions, fuel consumption reduction and $\mathrm{N} \& \mathrm{~V}$ ".

\section{Acknowledgements}

The Spanish Oceanographic Institute deserves a special mention for the initiative and the motivation of all the players: shipyards, suppliers, and consultants on achieving the objectives of the project. Some of the results presented were obtained within the framework of the BESST and SILENV project. Gratitude goes to all the partners that have participated. Finally, it is important to note that the building of the research vessel "Ramón Margalef" has benefitted from EU Regional Structural Funds under Grant FICTS-2011-03-01.

\section{References}

[1] ADVERSON, Vendittis 2000, Radiated noise characteristics of a modern cargo ship.

[2] ANSI/ASA S12.64-2009/Part 1: Quantities and Procedures for Description and Measurement of Underwater Sound from Ship - Part 1: General Requirements.

[3] BELTRÁN P., SALINAS R. et al., SILENV Project D 2.2.1.

[4] BELTRÁN, P. 2001. Noise vibration on ship prediction: Basic engineering tool to fulfil the current requirements of comfort and quality. Naval Engineering Magazine.

[5] BELTRÁN, P. et al., 2006. "Silent Fishing Vessels. A milestone for small and big Spanish shipyards. Lessons learnt”. Naval Engineering Magzine.

[6] BELTRÁN, P. 2007. The Fishing Research Vessel "Miguel Oliver". Naval Engineering Magazine.

[7] BELTRÁN P. 2008. Oceanographic Ship "Miguel Oliver": The excellence on Noise and Vibration on board fulfilling ICES-Na209. First Prize $47^{\text {th }}$ Congress of Naval Engineering and Maritime Industry.

[8] BELTRÁN, P. \& TESORERO, M.A. "Spanish Shipbuilding ready to meet the new and demanding Environmental Requirements: New Challenges and Business Opportunities". Ingeniería Naval 887. Silver Price $49^{\text {th }}$ Congress of Naval Engineering and Maritime Industry.

[9]. BESST- Breakthrough in European Ships and Shipbuilding Technologies \& SILENV- Ships oriented Innovative Solutions to Reduce Noise 
\& Vibration, project funded by the EC within the $7^{\text {th }}$ FP.

[10] DNV-Silent Class Notation. Part 6, Chapter 21, January 2011.

[11] ICES Regulation № 209.

[12] KIPPLE, NVSSCCD Report, Coral Princess Underwater Acoustic Levels (2004).

[13] KIPPLE, NVSSCCD Report, Volendam Underwater Acoustic Levels (2004).
[14] KIPPLE, Southeast Alaska Cruise Ship Underwater Acoustic Noise. Naval Surface Warfare Center- Detachment Bremerton Technical report NSW CCD-71-2002-574 (2002).

[15] ISO 2922/2000 Acoustics - Measurement of airborne sound emitted by vessels on inland waterways and harbours. 